\title{
Governance and Human Development in Gulu District: A Case Study of Gulu Municipality
}

\author{
Biryomumeisho Justus $^{1 *}$, Akena Denis Uma ${ }^{2}$ \\ ${ }^{1}$ Department of Accounting and Finance, Gulu University, Gulu, Uganda \\ ${ }^{2}$ Department of Public Administration and Management, Gulu University, Gulu, Uganda \\ Email: "justus_b@hotmail.com,umadenis@gmail.com
}

Received 27 September 2015; accepted 25 April 2016; published 28 April 2016

Copyright (C) 2016 by authors and Scientific Research Publishing Inc.

This work is licensed under the Creative Commons Attribution International License (CC BY). http://creativecommons.org/licenses/by/4.0/

\section{c) (i) Open Access}

\begin{abstract}
The study aims at examining governance in the promotion of human development in Gulu District with particular reference to Gulu Municipality. The research was conducted using 387 participants in Gulu Municipality and adopted quantitative design with random stratified sampling technique. The data were analyzed using Pearson correlation coefficient, regression and descriptive statistics. The study indicated that $200(51.7 \%)$ were male and $187(48.3 \%)$ were female. The study finds that greater levels of accountability, participation and absence of corruption are associated with greater levels of human development. Correlation analysis results showed that there is a significant positive relationship between accountability and human development $(r=0.351, p=$ 0.000). There is a significant positive relationship between government efficiency, participation and control of corruption and human development $(r=0.317, p=0.000 ; r=0.378, p=0.000$; and $r$ $=0.416, p=0.000$ ) respectively. The relationship between bribery and human development is very low and insignificant. Overall, there is a significant positive relationship between good governance and human development $(r=0.477, p=0.000)$. The regression analysis shows that good governance explains $24.4 \%$ of the variations in human development (Adjusted $R^{2}=0.244$, Sig. $F$ change $\mathbf{0 . 0 0 0}$ ). The study findings indicate that the best predictors of human development were accountability, participation and control of corruption. The worst predictor was government efficiency. The study concludes that bribery is neither associated with human development nor any attributes of good governance.
\end{abstract}

\section{Keywords}

Governance, Human Development, Accountability, Corruption, Transparency, Participation, Local Government

\footnotetext{
*Corresponding author.
} 


\section{Introduction}

Globally, there has been increased albeit fragmented debate on governance and human development. While governance refers to the manner in which power is exercised in the management of the affairs of a nation and its relations with other nations (African Development Bank-AfDB, 2008), human development is the expansion of the choices; people have to lead lives that they value [1] [2]. Various studies on governance and human development suggest that human development is almost impossible without good governance. Proponents of good governance argue that those who curtail it ultimately hinder human development. Former United Nations Secretary General, Koffi Annan, is quoted to have said "good governance is perhaps the single most important factor in eradicating poverty and promoting development" [3]. However, the specific nature of the relationship between good governance and human development has been scarcely brought to scrutiny by researchers and development partners [4] [5]. This paper attempts to address the gap.

While much has been achieved in the initiatives for good governance, improving good governance is paramount at local, national, regional and international level. At international level, the United Nations (UN) and its agencies, in consultation with development partners and international financial institutions, have been at the fore front in championing initiatives for good governance. For example, based on the accumulated knowledge and information gained from its global experience, the United Nations Development Program (UNDP) compiled a set of elements to improve the understanding of good governance [6] coupled with the publication of the Human Development Report in 1990. At regional level, the African Development Bank (AfDB) authored the Governance Strategic Directions and Action Plan (GAP) for 2008-2012 and 2014-2018 as guides for regional member states to improve good governance in Africa.

At both the national and local levels, meeting the Millennium Development Goals (MDGs) in Uganda is dependent upon meeting the goals in the north of the country, which has been falling behind the rest of the country in terms of human development progress mainly because of the protracted, but now ended, civil war [7]. A resolution of the MDGs was made by the UN in 2000 as the set targets for the international development community. According to the national survey figures, overall levels of poverty fell from $56 \%$ in 1992 to $24.5 \%$ in 2009 [7]. While progress has been gradual across the country, it has been unevenly distributed with the northern region generally experiencing a lower rate of poverty reduction than other regions [6]-[9].

In an earlier study in Northern Uganda, a comparison of poverty levels in 1992 and 2002 revealed wide variations among counties and sub-counties [7]. In other words, even at the local level within the northern region, the development and poverty reduction experience remains mixed [7]-[9]. [10] states that in Gulu and Kitgum districts, life expectancy is lowest with just 29 years compared to the national average of just over 50 years. In this regard, civil society organizations and NGOs have since been implementing governance programs with the goal to promote human development [10].

This paper seeks to examine the influence of good governance on human development in Gulu District, Northern Uganda an economy that is considered as developing despite decades of conceptualizing, formulating and implementing various types of economic policies and good governance initiatives. Northern Uganda has recently emerged from a devastating two decade war that pitied government against the Lords Resistance Army rebels. Moreover, there is very little available research on the linkage between good governance and human development, which provides motivation for this study. Thus, we regard human development as providing an indispensable test in any consideration of good governance debate. If good governance has no measurable impact on human development its status as a fundamental cause raises questions on its utility [11]. The paper is organized as follows: Section 2 provides the literature review and hypotheses development, Section 3 deals with methods, data types, variables measurement and data analysis; Section 4 is discussion while section 5 concludes.

\section{Literature Review}

\subsection{Good Governance}

Researchers and policy makers posit that governance is one of the critical factors explaining the divergence in performance across developing countries. While supporting the governance model, researchers and policy makers have provided different good governance explanations to illuminate its meaning. The World Bank group defines governance as "the manner in which power is exercised in the management of the affairs of a nation and its relations with other nations" [12]. [13] explains that governance consists of the traditions and institutions 
through which authority in a country is exercised. [13] provides Worldwide Governance Indicators (WGI) along six dimensions: voice and accountability; political stability; government effectiveness; regulatory quality; rule of law and control of corruption. Four specific elements of governance are: accountability (officials being answerable for government behavior), participation, predictability and transparency [12]. For [6], based on a longstanding research program at the World Bank, they capture six key dimensions of governance. Furthermore, over time, [6] identifies nine characteristics of good governance as participation, rule of law, transparency, responsiveness, consensus orientation, equity, effectiveness and efficiency, accountability and strategic vision. According to [8] [14] [15], good governance is categorized into eight major attributes not very different from [12] classification above. To [14], transparency means that decisions taken and their enforcement are done in a manner that follows rules and regulations. As for accountability, it involves designing effective avenues of recourse or redress to affected persons [15].

In international affairs, analysis of good governance involves scrutiny of stakeholder relationships ranging between citizens to elected officials to governments and markets [12] [16] [17]. A variety of country level initiatives and international movements put emphasis on various types of governance reform based on their own needs and agendas [18]-[20].

\subsection{Human Development}

The [1] defines this concept as expanding the choices people have to lead lives that they value. The report identifies important choices to include knowledge, healthy life, education and decent standard of living, political freedom, guaranteed human rights and self-respect. The [21] stresses that education boosts peoples' self-confidence, enables them find better jobs, make demands on government for health-care and mortality. People who are poor, unhealthy and illiterate simply have fewer choices in life. This means that failure to implement education policies adversely affects choices underpinning human development. Similarly, [22] argue that enjoying a long and healthy life, education, access to resources and participating in societal decision making enable citizens live better quality life.

Researchers and policy makers recognize the fact that despite the benefits currently manifesting in Northern Uganda, poverty in the country remains heavily regionalized [23]. The current [24] explicitly recognizes the need to integrate northern Uganda into the mainstream development of the country. The NDP does propose strategies for this region, including a commitment to the second Peace, Recovery and Development Plan (PRDP 2) for the north. PRDP 2 is expected to improve community participation and ownership of services, promote economic recovery and revamp the quality of life of the beneficiary communities in Northern Uganda [24].

\subsection{Relationship between Good Governance and Human Development}

Until recently, scholars like [18] [25] have began to view that the literature on governance and/for sustainable development amounted to a great deal of discursive smoke but little in the way of empirical fire. [22] believes that governance and/for sustainable development need to be better described and accounted for in an empirical study. [26] argues that policy makers continue to confront long lists of things that must be done to achieve good governance, with little guidance about how to pick and choose among them as priorities. In this perspective, some researchers have attempted to establish linkages between good governance and human development. For instance, [26], using panel data analysis, finds the evidence that good governance and past human development determines present human development in India. [4], [18]'s study in Nigeria found that control of corruption and voice and accountability have no significant negative impact on human development.

Investigating the empirical relationship between corruption and economic growth, [27] finds that a 1 percent increase in the corruption level reduces the growth by about 0.72 percent. [28] investigates the nexus between corruption and human development empirically by using a full information maximum likelihood approach and finds a negative correlation. Examining the impact of corruption on human development, [29] [30] reveals that there is a statistically significant negative relationship between corruption indexes and human development.

[6] shows that there is quantitative evidence that a positive correlation exists between measures of the quality of governance, broadly defined into six indicators, and various measures of economic development. For instance, this correlation finding is debated by [13] [31] [32] who find no significant differences in the scores on good governance of high-growth and low-growth developing countries. The studies above suggest that the relationship between good governance and human development are still inconclusive. This paper explores this relation- 
ship in developing country Uganda contextualized within a geographical region that had emerged from a devastating two decade conflict.

\subsection{Hypotheses}

Based on the above, the following hypotheses were tested (Figure 1).

\section{Methods}

\subsection{Population and Sample}

The population of the study is the community, non-governmental and community-based organizations within four divisions of the municipality namely Pece, Laroo, Layibi and Bardege. The sample selection was convenience sampling-based and stratified random sampling according to community members, health workers, teachers, local leaders, employees in both non-governmental and community-based organizations. The community members, heath workers, teachers, local leaders, NGOs and CBOs were physically visited by the researchers and three assistants with an introductory letter from the faculty for a period of one month (January, 2015). All the sampled community members returned the questionnaires filled with the help of the researcher and assistants. The rest of the respondents were left to fill the questionnaire on their own and promised to have filled them by the next appointment visit. In all, 590 questionnaires were served to respondents out of which 387 were collected and found usable for the purpose of the study.

\subsection{Types and Data Sources}

Both primary and secondary data were collected for this empirical research. Primary data was collected using a structured questionnaire while secondary data was collected from archival records of local government, NGOs and CBOs. The questionnaire was developed based on the literature on governance and human development [13] [14] [20]. All questionnaire items (27 for good governance and 11 for human development) were measured on a five-point scale ( 1 = strongly disagree, 5 = strongly agree) and pilot tested. The questionnaires were pre-tested on four faculty experts before being administered to respondents. Content Validity Index (CVI) of 0.8759 was calculated by tallying the results of the faculty experts based on the degree to which the experts agree on the relevance and clarity of the items. In addition, the instrument was piloted on ten people working in the local government in the municipality. These were conveniently approached by the research assistants, being familiar and born and raised in the municipality. The filled questionnaires were then coded, sorted, entered analyzed using SPSS Version 20. Reliability reflects the stability and consistency of an instrument measuring a concept [33] [34]. In view of the characteristics of the pilot test instruments used in this study, the inter-item reliability consistency alpha was used to measure its reliability. Chronbach's alpha values of 0.805 and 0.795 for good governance and human development respectively were computed and presented in Table 1 below. This indicates that values are within the acceptable range of well above the 0.70 cut-off proposed by [34]-[36]. Hence the instrument items were appropriate for further analysis.

In order to assess the suitability of the data for factor analysis, we inspect the correlation matrix for coefficients of 0.3 and above, and calculating the Kaiser-Meyer-Olkin Measure of Sampling Adequacy (KMO) and Bartlett's Test of Sphericity [35]. When the KMO exceeds 0.6 and Bartlett's test of sphericity is large and significant, then factor analysis is suitable (Leech et al., 2005). Furthermore, to be able to apply principal component analysis in this study, both the KMO and Bartlett's test were computed. In the pilot study, the KMO measure is 0.746 , Sig. $=0.000$ for good governance and 0.676 , Sig. $=0.000$ for human development. These measures are all well above the 0.60 proposed by [35] indicating that there were sufficient items for each variable. The principal

\begin{tabular}{|l|l|}
\hline $\begin{array}{l}\text { Good Governance } \\
\text {-Government efficiency } \\
\text { •Controlof Corruption } \\
\text { •Participation } \\
\text {-Accountability } \\
\text {-Bribery }\end{array}$ & $\longrightarrow \begin{array}{l}\text { Human Development } \\
\bullet \text { Democracy } \\
\bullet \text { Public services } \\
\bullet \text { Economic empowerment }\end{array}$ \\
\hline
\end{tabular}

Figure 1. Example of a figure caption (figure caption). 
component analysis results suggested that the good governance item components accounted for $67.4 \%$ total variance explained while human development items accounted for $72.3 \%$ total variance explained using the Kaiser criterion [35]. The results from the pilot study suggested that the instrument was very reliable for further testing.

The results of the sample data are shown in Table 2.

As indicated in Table 2, 200 (51.7\%) of the respondents were male and 187 (48.3\%) were females. The table also shows that majority 134 (34.6\%) respondents were certificate holders and $47.5 \%$ were aged below 30 years.

\subsection{Variable Measurement}

The independent variable is good governance measured by five attributes: accountability, government effectiveness, participation, control of corruption and bribery.

Accountability involves establishing effective avenues of recourse or redress to affected persons when stakeholders' responsibilities and obligations are not fulfilled in ensuring successful outcomes [19]. Government efficiency means the quality of the public or civil service and the degree to which it is independent from the political process [13]. Control of corruption indicates the extent to which public power is used for private gain and the extent to which public power is controlled by private interests [13]. Bribery refers to the offering, giving, accepting or soliciting of an advantage as an inducement for an action which is illegal or a breach of trust [37]-[40].

The dependent variable is human development measured by eight items. It is difficult to measure a firm's human development level since it does not necessarily equal the sum of the constructs used in this study.

\subsection{Independent Variable}

Good governance as an independent variable is measured by 26 items (see Appendix).

[37] suggests that the principal components analysis (PCA) is a data reduction technique used to reduce a large number of variables to a smaller set of underlying factors that summarize the essential information contained in the variables. The decision about which principal components to retain depends on the percentage of the variance accounted for by the variable, the absolute variance accounted for by each principal component (PC) and whether the component can be meaningfully interpreted [37] [38]. This research study uses varimax with Kaiser Normalization rotation method developed by [36]. In this method, the principal components with Eigen values greater than 1 are retained for further analysis [34]-[36] [41].

An inspection of results from the PCA indicate that the Kaiser-Meyer-Olkin Measure of Sampling Adequacy (KMO) is 0.736 well above the 0.60 proposed cut off [35] and Barlett's Test of Sphericity is large $\chi^{2}=$ 1521.677) and significant as shown in Table 3 below. These results satisfied the necessary conditions for use of PCA in this study.

Results in Table 4 show five components (see Table 5 and Table 6) with Eigen values greater than 1 accounted for $70.653 \%$ of the variance in good governance. The first component labeled government efficiency accounted for $31.516 \%$; the second component labeled accountability accounted for $10.640 \%$; the third component labeled control of corruption accounted for $10.379 \%$; the fourth component labeled bribery accounted for 9.449\% while the fifth component labeled participation accounted for $8.579 \%$ of the variance in good governance.

[35] suggests that you think carefully before including two variable constructs with a bivariate correlation of,

Table 1. Hypotheses of the study.

\begin{tabular}{cc}
\hline Hypothesis & Narrative \\
\hline $\mathrm{H}_{1}$ & There is a significant positive relationship between government efficiency and human development. \\
$\mathrm{H}_{2}$ & There is a significant positive relationship between participation and human development. \\
$\mathrm{H}_{3}$ & There is a significant positive relationship between accountability and human development. \\
$\mathrm{H}_{4}$ & There is a significant negative relationship between bribery and human development. \\
$\mathrm{H}_{6}$ & There is a significant positive relationship between good governance and human development.
\end{tabular}


Table 2. Sample characteristics.

\begin{tabular}{|c|c|c|}
\hline Gender of respondents & Frequency & Percent \\
\hline Male & 200 & 51.7 \\
\hline Female & 187 & 48.1 \\
\hline \multicolumn{3}{|l|}{ Age of respondents } \\
\hline Below 20 & 14 & 3.6 \\
\hline $20-29$ & 184 & 47.5 \\
\hline $30-39$ & 90 & 23.3 \\
\hline $40-49$ & 46 & 11.9 \\
\hline $50-59$ & 36 & 9.3 \\
\hline $60+$ & 17 & 4.4 \\
\hline Total & 387 & 100.0 \\
\hline \multicolumn{3}{|l|}{ Educational level of respondents } \\
\hline Primary & 6 & 1.6 \\
\hline Secondary & 39 & 10.1 \\
\hline Certificate & 134 & 34.6 \\
\hline Diploma & 111 & 28.7 \\
\hline Degree & 82 & 21.2 \\
\hline Post Graduate & 14 & 3.6 \\
\hline Others & 1 & .3 \\
\hline Total & 387 & 100.0 \\
\hline \multicolumn{3}{|l|}{ Position } \\
\hline Health Worker & 77 & 19.9 \\
\hline Teacher & 69 & 17.8 \\
\hline NGO Employee & 30 & 7.8 \\
\hline CBO Employee & 39 & 10.1 \\
\hline Local Leader & 24 & 6.2 \\
\hline Local Resident/Community member & 148 & 38.3 \\
\hline Total & 387 & 100.0 \\
\hline
\end{tabular}

Source: Primary Data.

Table 3. KMO and Bartlett’s test for good governance.

\begin{tabular}{ccc}
\hline \multicolumn{2}{c}{ KMO and Bartlett's Test } & \\
\hline Kaiser-Meyer-Olkin Measure of Sampling Adequacy. & 0.736 \\
Bartlett's Test of Sphericity & Approx. Chi-Square & 1521.677 \\
& df & 78 \\
\hline
\end{tabular}

Source: Primary Data. 
Table 4. Total variance explained.

\begin{tabular}{|c|c|c|c|c|c|c|c|c|c|}
\hline \multirow{2}{*}{ Component } & \multicolumn{3}{|c|}{ Initial Eigenvalues } & \multicolumn{3}{|c|}{ Extraction Sums of Squared Loadings } & \multicolumn{3}{|c|}{ Rotation Sums of Squared Loadings } \\
\hline & Total & $\%$ of Variance & Cumulative \% & Total & $\%$ of Variance & Cumulative \% & Total & $\%$ of Variance & Cumulative \% \\
\hline 1 & 4.097 & 31.516 & 31.516 & 4.097 & 31.516 & 31.516 & 2.256 & 17.357 & 17.357 \\
\hline 2 & 1.383 & 10.640 & 42.156 & 1.383 & 10.640 & 42.156 & 2.191 & 16.855 & 34.212 \\
\hline 3 & 1.349 & 10.379 & 52.535 & 1.349 & 10.379 & 52.535 & 1.763 & 13.559 & 47.771 \\
\hline 4 & 1.228 & 9.449 & 61.984 & 1.228 & 9.449 & 61.984 & 1.634 & 12.570 & 60.341 \\
\hline 5 & 1.115 & 8.579 & 70.563 & 1.115 & 8.579 & 70.563 & 1.329 & 10.222 & 70.563 \\
\hline 6 & 0.731 & 5.622 & 76.185 & & & & & & \\
\hline 7 & 0.647 & 4.981 & 81.165 & & & & & & \\
\hline 8 & 0.542 & 4.166 & 85.331 & & & & & & \\
\hline 9 & 0.491 & 3.777 & 89.108 & & & & & & \\
\hline 10 & 0.457 & 3.517 & 92.625 & & & & & & \\
\hline 11 & 0.406 & 3.127 & 95.752 & & & & & & \\
\hline 12 & 0.310 & 2.385 & 98.137 & & & & & & \\
\hline 13 & 0.242 & 1.863 & 100.000 & & & & & & \\
\hline
\end{tabular}

Extraction Method: Principal Component Analysis.

Table 5. Rotated component matrix.

\begin{tabular}{|c|c|c|c|c|c|}
\hline \multicolumn{6}{|c|}{ Rotated Component Matrix } \\
\hline & \multicolumn{5}{|c|}{ Component } \\
\hline & 1 & 2 & 3 & 4 & 5 \\
\hline Sufficient Health Facilities & 0.802 & & & & \\
\hline Salary Payments & 0.710 & & & & \\
\hline Quality Services & 0.681 & & & & \\
\hline Access to Education & & 0.804 & & & \\
\hline Spending on Buildings & & 0.771 & & & \\
\hline Regular Elections & & 0.693 & & & \\
\hline Rules and Policies & & & 0.817 & & \\
\hline Control of Corruption & & & 0.710 & & \\
\hline Leaders’ Responsibilities & & & 0.601 & & \\
\hline Trust in Institutions & & & & 0.813 & \\
\hline Bribery & & & & 0.807 & \\
\hline Information Dissemination & & & & & 0.851 \\
\hline Consultation of Urban Poor & & & & & 0.611 \\
\hline Cronbach’s Alpha & 0.714 & 0.734 & 0.659 & 0.620 & 0.738 \\
\hline $\begin{array}{l}\text { Extraction Method: Principal Compo } \\
\text { Rotation Method: Varimax with Kais }\end{array}$ & ion. & & & & \\
\hline
\end{tabular}

${ }^{\mathrm{a}}$ Rotation converged in 7 iterations. Source: Primary Data. 
Table 6. Summary of components.

\begin{tabular}{|c|c|c|}
\hline No. & Component & Item \\
\hline \multirow{3}{*}{1} & \multirow{3}{*}{ Government efficiency } & Sufficient Health Facilities \\
\hline & & Salary Payments \\
\hline & & Quality Services \\
\hline \multirow{3}{*}{2} & \multirow{3}{*}{ Accountability } & Access to Education \\
\hline & & Spending on Buildings \\
\hline & & Regular Elections \\
\hline \multirow{3}{*}{3} & \multirow{3}{*}{ Control of corruption } & Rules and Policies \\
\hline & & Control of Corruption \\
\hline & & Leaders' Responsibilities \\
\hline \multirow{2}{*}{4} & \multirow{2}{*}{ Bribery } & Trust in Institutions \\
\hline & & Bribery \\
\hline \multirow{2}{*}{5} & \multirow{2}{*}{ Participation } & Information Dissemination \\
\hline & & Consultation of Urban Poor \\
\hline
\end{tabular}

Source: Primary Data.

say, 0.7 or more in the same analysis. The highest correlation in Table 8 is 0.793 suggesting a test of the normality assumption.

In fulfillment of normality assumption a data set is considered normal if the values of skewness fall within the range of +2 to -2 while kurtosis values do not exceed the range of +7 to -7 [35]. In regard to the above threshold for justifying the normality of data, all skewness values and kurtosis values in Table 7 fall within the acceptable range as advocated by [35]. Therefore, all observed data for items considered under this study are normal as indicated in Table 7 and all constructs are retained for analysis.

\subsection{Correlation Analysis}

Correlation analysis was carried out to detect any autocorrelation between human development and each of the constructs of good governance. Such bivariate analysis was undertaken using Pearson correlation. In addition, correlation coefficients are also intended to attest the construct validity of the constructs of good governance and to check for multicollinearity [35]. The inter-variable correlations results are shown in Table 8.

From the results of correlations analysis as depicted in Table 8, control of corruption emerged as the feature with the best predictor on other good governance constructs $(r=0.585, \mathrm{p}<0.01)$ and on human development $(\mathrm{r}$ $=0.416, \mathrm{p}<0.01$ ). All the constructs of good governance were positively statistically significant at all levels ( $\mathrm{p}$ $<0.01$ and $\mathrm{p}<0.05$ ) hence the hypotheses were achieved. All good governance constructs were significant and positively correlated with human development $(\mathrm{p}<0.01)$ with the exception of bribery which, mostly, is not statistically significant at any reasonable level. Most importantly, bribery had a positive non-significant relationship with human development $(r=0.085, \mathrm{p}>0.01)$ but a negative statistically significant correlation with government efficiency $(r=-0.200, p<0.01)$. This implies that bribery is neither associated with human development nor any attributes of good governance. Moreover, bribery impacts negatively on government efficiency.

\subsection{Regression}

Table 9 indicates that the independent variable (good governance) has adequate explanatory power on the dependent variable (human development) to the magnitude of $24.4 \%$ (Adj. $\mathrm{R}^{2}=0.244, \mathrm{P}<0.001$ ).

Table 10 above presents the analysis of variance (ANOVA) results of F-test. One-way ANOVA test results reveal that there is significant difference between good governance indicators and human development $(\mathrm{F}=$ 25.823, $\mathrm{p}=0.000$ ). 
Table 7. Descriptive statistics.

\begin{tabular}{ccccccccccc}
\hline & $\mathrm{N}$ & Minimum & Maximum & Mean & Std. Deviation & \multicolumn{2}{c}{ Skewness } & \multicolumn{2}{c}{ Kurtosis } \\
\cline { 2 - 10 } & Statistic & Statistic & Statistic & Statistic & Statistic & Statistic & Std. Error & Statistic & Std. Error \\
\hline Human Development & 386 & 1 & 5 & 2.96 & 0.514 & 0.041 & 0.124 & 0.207 & 0.248 \\
Good Governance & 387 & 1 & 5 & 3.46 & 0.682 & -0.396 & 0.124 & 0.060 & 0.247 \\
Accountability & 387 & 1.33 & 5.00 & 3.6047 & 0.83231 & -0.577 & 0.124 & -0.592 & 0.247 \\
Government Efficiency & 387 & 1.00 & 5.00 & 3.1537 & 1.18179 & -0.246 & 0.124 & -1.061 & 0.247 \\
Participation & 387 & 1.00 & 5.00 & 3.5788 & 1.15209 & -0.362 & 0.124 & -1.032 & 0.247 \\
Absence of Corruption & 387 & 1.00 & 5.00 & 4.3075 & 1.02357 & -1.387 & 0.124 & 0.915 & 0.247 \\
Bribery & 387 & 1.00 & 5.00 & 2.6822 & 1.37135 & 0.242 & 0.124 & -1.299 & 0.247 \\
Valid N (listwise) & 386 & & & & & & & & & \\
\hline
\end{tabular}

Source: Primary Data.

Table 8. Correlation analysis.

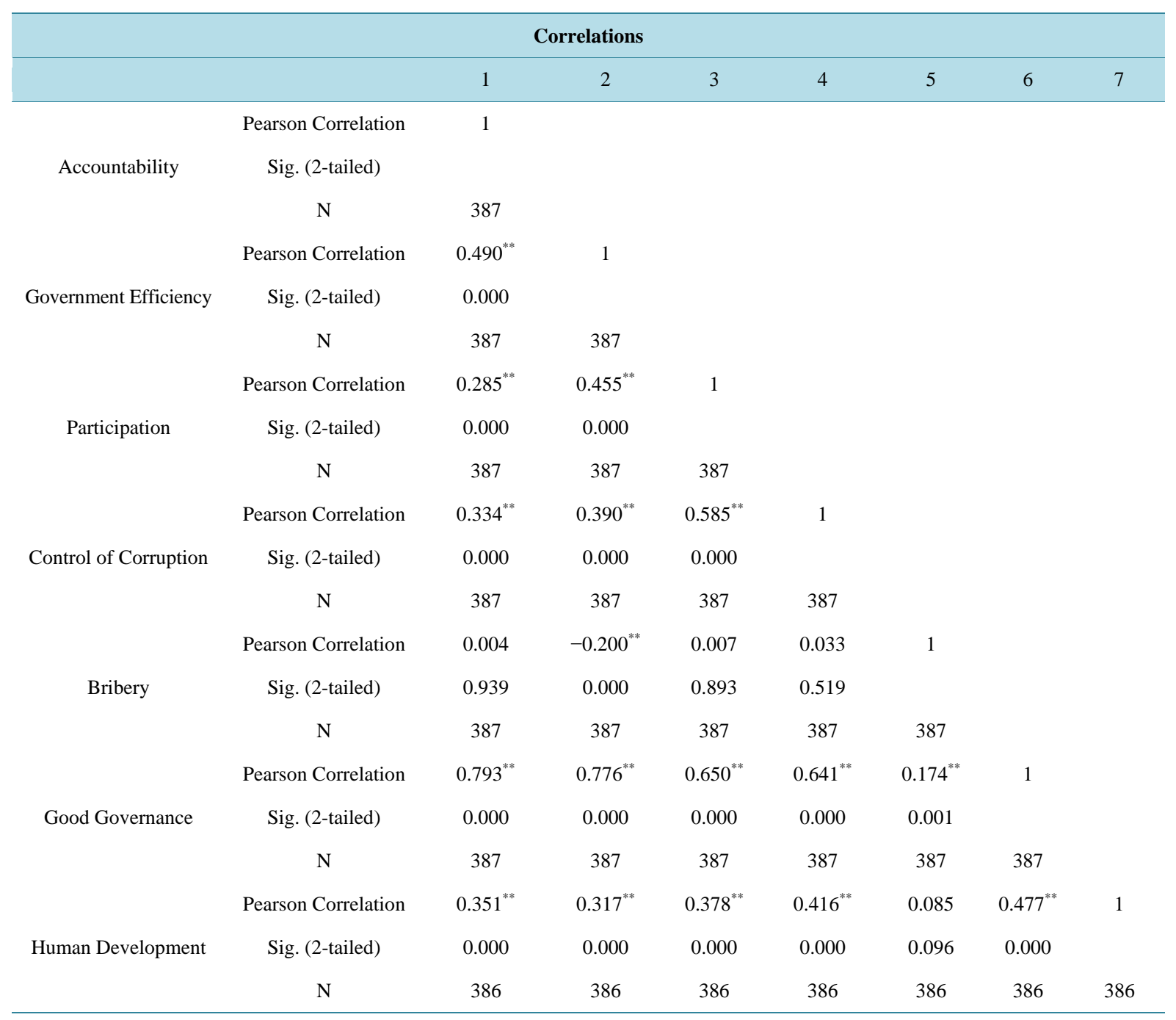

${ }^{* *}$ Correlation is significant at the 0.01 level (2-tailed). ${ }^{*}$ Correlation is significant at the 0.05 level (2-tailed). Source: Primary Data. 
Table 9. Model summary.

\begin{tabular}{|c|c|c|c|c|c|c|c|c|c|}
\hline \multirow[b]{2}{*}{ Model } & \multirow[b]{2}{*}{$\mathrm{R}$} & \multirow[b]{2}{*}{ R Square } & \multirow[b]{2}{*}{ Adjusted R Square } & \multirow{2}{*}{$\begin{array}{l}\text { Std. Error of } \\
\text { the Estimate }\end{array}$} & \multicolumn{5}{|c|}{ Change Statistics } \\
\hline & & & & & $\begin{array}{l}\text { R Square } \\
\text { Change }\end{array}$ & F Change & df1 & df2 & $\begin{array}{l}\text { Sig. F } \\
\text { Change }\end{array}$ \\
\hline 1 & 0.504 (a) & 0.254 & 0.244 & 0.447 & 0.254 & 25.823 & 5 & 380 & 0.000 \\
\hline
\end{tabular}

${ }^{\mathrm{a}}$ Predictors: (Constant), Bribery, Accountability, Participation, Corruption Absence, Government Efficiency. ${ }^{\mathrm{b}}$ Dependent Variable: Human Development. Source: Primary Data.

Table 10. ANOVA (b).

\begin{tabular}{ccccccc}
\hline Model & & Sum of Squares & Df & Mean Square & F & Sig. \\
\hline 1 & Regression & 25.753 & 5 & 5.151 & 25.823 & 0.000 (a) \\
& Residual & 75.795 & 380 & 0.199 & & \\
& Total & 101.548 & 385 & & & \\
& & &
\end{tabular}

${ }^{\mathrm{a} P r e d i c t o r s: ~(C o n s t a n t), ~ B r i b e r y, ~ A c c o u n t a b i l i t y, ~ P a r t i c i p a t i o n, ~ C o r r u p t i o n ~ A b s e n c e, ~ G o v e r n m e n t ~ E f f i c i e n c y . ~}{ }^{\mathrm{b}}$ Dependent Variable: Human Development. Source: Primary Data.

Inspection of the $\mathrm{B}$ coefficients in Table 11 shows that control of corruption is the most influential explanatory variable $(\mathrm{B}=0.228, \mathrm{p}=0.000)$ and the least explanatory variable is government efficiency $(\mathrm{B}=0.084, \mathrm{p}=$ 0.139). Further, from Table 8, the regression coefficients indicated that the dimensions of control of corruption $(B=0.228, p=0.00)$, accountability $(B=0.190, p=0.00)$ and participation $(B=0.152, p=0.009)$ exerted statistically significant influence on overall human development followed by the dimension of bribery $(B=0.093$, $\mathrm{p}=0.054)$. Thus hypotheses H2, H3, H4 and H6 were achieved. Government efficiency $(B=0.084, p=0.139)$ was not statistically significant, hence hypothesis H1 is not met. This study suggests that greater levels of accountability, participation and control of corruption are associated with greater levels of human development. Most importantly, bribery had a positive non-significant relationship with human development $(B=0.093, \mathrm{p}>$ 0.001) and a negative correlation with government efficiency. Hence, hypothesis H5 was not achieved. This implies that bribery is neither associated with human development nor any attributes of good governance.

\section{Discussion}

The study results indicate that corruption affects social services delivery particularly education and health care. As monies are embezzled by public officials it ends up creating income inequality. It concurs with the statement that corruption in the country has mainly impacted ordinary people, as money intended for public services including life-saving treatment or infrastructure projects have all been but misappropriated [40] [42] [43]. This confirms that lack of political will has crippled Uganda's anti-corruption institutions, undermining their efforts through political interference, harassment, and threats. This results into high income disparity which was confirmed by the respondents.

Participation was significant and positively correlated with government efficiency and human development. This implies that participation is associated with government efficiency and human development. Participation had a negligible positive non significant relationship with bribery. Generally, on participation, the majority of the respondents noted that there is low participation level in development. This can be explained by the fact that there are arrests and intimidation of activists and there is need to strengthen the protection accorded to investigators, prosecutors and witnesses. This has discouraged participation in activities. This is not in line with [43] which stated that communities should participate in decision-making through Health Unit Management Committees and Village Health Team.

Accountability was significantly and positively correlated with human development. This suggests that there is no proper accountability for public funds, human development cannot be achieved. This is consistent with the literature review that lack of accountability to clients and the health system removes possible natural motivational mechanisms [43] [44]. This confirms that there has been mismanagement of funds available to the different blocks of the health system. A joint World Bank, Ministry of Health, and Ministry of Finance Planning and Economic Development (MoFPED) study revealed that the health sector loses about UGX36.7 billion annually to waste through health worker absenteeism, expired drugs, and poor payroll management [37]. 
Table 11. Regression coefficients (a).

\begin{tabular}{|c|c|c|c|c|c|c|}
\hline \multirow[t]{2}{*}{ Model } & & \multicolumn{2}{|c|}{ Unstandardized Coefficients } & \multirow{2}{*}{$\begin{array}{c}\text { Standardized Coefficients } \\
\text { Beta }\end{array}$} & \multirow[t]{2}{*}{$\mathrm{t}$} & \multirow[t]{2}{*}{ Sig. } \\
\hline & & $\mathrm{B}$ & Std. Error & & & \\
\hline \multirow[t]{6}{*}{1} & (Constant) & 1.594 & 0.129 & & 12.388 & 0.000 \\
\hline & Accountability & 0.117 & 0.032 & 0.190 & 3.667 & 0.000 \\
\hline & Government Efficiency & 0.037 & 0.025 & 0.084 & 1.482 & 0.139 \\
\hline & Participation & 0.068 & 0.026 & 0.152 & 2.638 & 0.009 \\
\hline & Control of Corruption & 0.114 & 0.028 & 0.228 & 4.049 & 0.000 \\
\hline & Bribery & 0.035 & 0.017 & 0.093 & 2.016 & 0.054 \\
\hline
\end{tabular}

${ }^{\mathrm{a}}$ Dependent Variable: Human Development. Source: Primary Data.

This study suggests that greater levels of accountability, participation and control of corruption are associated with greater levels of human development. Results of this study are supported by previous studies [24] [34] [35], [38].

In line with [31]'s argument, the main policy implications of our findings are that countries can increase human wellbeing by making governance systems more productive and diverting the productivity gains to investment in different aspects of human development such as education and health. Good governance is a key in human development [26]. It has attributes of being consensus oriented, equitable and inclusiveness, participation, transparent, government effectiveness and efficiency, follow rule of law, accountable, and responsiveness [14] [40].

\section{Conclusion}

Bad governance is being increasingly regarded as one of the root causes of all evil within our societies. Since governance is the process of decision-making and the process by which decisions are implemented, an analysis of governance should focus on the formal and informal actors involved in decision-making and implementing the decisions made and the formal and informal structures that have been set in place to arrive at and implement the decisions. This study examines to examine the relationship between good governance and human development in Gulu District Local Government. Results from this study suggest that greater levels of accountability, participation and control of corruption are associated with greater levels of human development. On the other hand, issues of government efficiency and effectiveness and bribery retard human development if not checked. Future research may be focused on these issues.

\section{References}

[1] Human Development Report (2001) UNDP. http://www.undp.org

[2] Anand, S. and Sen, A. (2000) Human Development and Economic Sustainability. World Development, 28, $2029-2049$. http://dx.doi.org/10.1016/S0305-750X(00)00071-1

[3] Gisselquist, R.M. (2012) Good Governance as a Concept, and Why This Matters for Development Policy. WIDER Working Paper No.30. http://www.wider.unu.edu/publications/working-papers/2012/en_GB/wp2012-030/

[4] Essien, A.V. (2012) Human Development and Good Governance (Nigerian Case; 1996-2010). http://ssrn.com/abstract=2150466

[5] Ahmad, Z. and Saleem, A. (2014) Impact of Governance on Human Development. Pakistan Journal of Commerce and Social Sciences, 8, 612-628.

[6] Kaufmann, D., Kraay, A. and Mastruzzi, A. (2008) Worldwide Governance Indicators: 1996-2007. World Bank Policy Research Working Paper, 4654.

[7] Levine, S. (2009) UNDP Uganda: Poverty and Human Development in Northern Uganda. Uganda.

[8] Kwame, S.J. and Chowdhury, A. (2012) Is Good Governance Good for Development? United Nations Series on Development, Bloomsbury Academic, London and New York.

[9] Uganda Bureau of Statistics (2002, 2005) Uganda Population and Housing Main Report. Kampala, Uganda.

[10] Bukuluki, P. and Mugisha, J. (2010) Baseline Survey for Roco Kwo Programme. Care International in Uganda, Kam- 
pala.

[11] Kohler-Koch, B. and Rittberger, B. (2006) The Governance Turn in EU Studies. Journal of Common Market Studies, 44, 27-49. http://dx.doi.org/10.1111/j.1468-5965.2006.00642.x

[12] Khan, M.H. (2009) Governance, Growth and Poverty Reduction. In: Kumar, A.K., Ed., Readings in Human Development, Department of Economic and Social Affairs, United Nations, DESA Working Paper 75, Oxford University Press, UK.

[13] United Nations Development Programme (2014) Governance for Sustainable Development: Integrating Governance in the Post-2015 Development Framework. Discussion Paper.

[14] The United Nations Economic and Social Commission for Asia and the Pacific (2009) What Is Good Governance? http://www.unescap.org/resources/what-good-governance

[15] Wouters, J., Ninio, A., Doherty, T. and Cissé, H. (2015) Improving Delivery in Development: The Role of Voice, Social Contract, and Accountability. The World Bank Legal Review, 6. http://dx.doi.org/10.1596/978-1-4648-0378-9

[16] Abdellatif, A.M. (2003) Good Governance and Its Relationship to Democracy and Economic Development. Global Forum III on Fighting Corruption and Safeguarding Integrity. Seoul. ftp://pogar.org/LocalUser/pogarp/governance/aa/goodgov.pdf

[17] Agere, S. (2000) Promoting Good Governance. Common Wealth Secretariat. http://dx.doi.org/10.14217/9781848597129-en

[18] Terungwa, P., Jato, J. and Akwen, G.T. (2014) The Attainment of Sustainable Development in Nigeria: A Good Governance Perspective. Journal of Sustainable Development in Africa, 16.

http://www.jsd-africa.com/Jsda/Vol16No3-Sum14A/PDF/The\%20Attainment\%20of\%20SustDevp\%20in

[19] UNDP (2001) Human Development Report: Making New Technologies Work for Human Development. Oxford University Press, New York.

[20] Khan, M.H. (2004) State Formation in Palestine: Viability and Governance during a Social Transformation. Journal of Political Economy of the Middle East and North Africa, 2. www.allbusiness.com

[21] Shome, S. and Tondon, S. (2010) Balancing Human Development with Economic Growth: A Study of ASEAN 5. Annals of the University of Petrosani, Economics, 10, 335-348.

[22] Kail, R.V. and Cavanaugh, J.C. (2015) Human Development: A Life-Span View. Fifth Edition, Wadsworth, Cengage Learning, Independence.

[23] Hickey, S. (2013) Beyond the Poverty Agenda: Insights from the New Politics of Development in Uganda. World Development, 43, 194-206. http://dx.doi.org/10.1016/j.worlddev.2012.09.007

[24] National Development Plan 2010/2015.

http://opm.go.ug/assets/media/resources/30/National\%20Development\%20Plan\%202010:11\%20-\%202014

[25] Jasanoff, S. and Martello, M. (Eds.) (2004) Earth Politics: Local and Global in Environmental Governance. MIT Press, Cambridge.

[26] Pradhan, R.P. (2011) Good Governance and Human Development: Evidence from Indian States. Journal of Social and Development Science: JSDS, 1, 1-8.

[27] Ghosh, J. (2012) Accumulation Strategies and Human Development in India. Agrarian South: Journal of Political Economy, 1, 43-64. http://dx.doi.org/10.1177/227797601200100104

[28] Akhter, H.S. (2004) Is Globalization What It's Cracked Up to Be? Economic Freedom, Corruption, and Human Development. Journal of World Business, 39, 283-295. http://dx.doi.org/10.1016/j.jwb.2004.04.007

[29] Brinkman, R.L. and Brinkman, J.E. (2011) GDP as a Measure of Progress and Human Development: A Process of Conceptual Evolution. Journal of Economic Issues, XLV, 447-456. http://dx.doi.org/10.2753/JEI0021-3624450222

[30] Akçay, S. (2006) Corruption and Human Development. Cato Journal, 26.

[31] Nandha, M. and Smyth, R. (2013) Quality of Governance and Human Development.

[32] Misunderestimating Chronic Poverty? Exploring Chronic Poverty in Developing Countries Using Cross-Sectional Demographic and Health. Global Social Policy, 8, 45-79. http://dx.doi.org/10.1177/1468018107086087

[33] Sekaran, U. (2003) Research Methods for Business: A Skill Building Approach. 4th Edition, John Wiley \& Sons, Inc., Hoboken.

[34] Tabachinick, B.G. and Fidell, L.S. (2007) Using Multivariate Statistics. 5th Edition, Allyn and Bacon, New York.

[35] Hair, J.F., Black, W.C., Babin, B.J., Anderson, R.E. and Tatham, R.L. (2006) Multivariate Data Analysis. Vol. 6, Pearson Prentice Hall, Upper Saddle River.

[36] Kaiser, H. F. (1958) The varimax criterion for analytic rotation in factor analysis. Psychometrika, 23(3), 187-200. 
[37] Okwero, P., Tandon, A., Sparkes, S., McLaughlin, J. and Hoogeveen, J.G. (2010) Fiscal Space for Health in Uganda. Africa Human Development Series: World Bank Working Paper No. 186. The World Bank, Washington DC.

[38] Ottervik, M. (2011) Good Governance and Human Development: The Case of China and India. Paper STVK01, Department of Political Science, Lund University, Lund.

[39] Zulfiqar, M., Shakeel, S. and Azim, P. (2012) Economic Governance and Human Development: Evidence from Pakistan. Journal of Asian Development Studies, 1, 35-45.

[40] (2007) Uganda Human Development Report. http://hdr.undp.org/sites/default/files/uganda_national_human_development_report_2007.pdf

[41] Leech, N.L., Barrett, K.C. and Morgan, G.A. (2005) SPSS for Intermediate Statistics, Use and Interpretation. 2nd Edition, Lawrence Erlbaum Associates Inc., Mahwah.

[42] Transparency International (2013) The Business Principles for Countering Bribery Report. http://www.transparency.org/whatwedo/pub/business_principles_for_countering_bribery

[43] Ministry of Health (2010) The Second National Health Policy. Promoting People’s Health to Enhance Socio-Economic Development. http://apps.who.int/medicinedocs/en/d/Js18426en/

[44] Zulfiqar, M., Shakeel, S. and Azim, P. (2012) Economic Governance and Human Development: Evidence from Pakistan. Journal of Asian Development Studies, 1, 35-45.

[45] Grindle, M.S. (2010) Good Governance: The Inflation of an Idea. HKS Faculty Research Working Paper Series, RWP10-023, John F. Kennedy School of Government, Harvard University, Cambridge, MA. 


\section{Appendix: Questionnaire}

\section{Section A: Background Information of the Respondents}

(Please tick one appropriate answer for each of the social demographics information below)

1) Age in years

Under 20

$20-29$

$30-39$

$40-49$

$50-59$

$60+$

2) Gender

Male

Female

3) Marital Status

Single

Married/Living together

Separated/Divorced

Widowed

4) Level of education

Primary

Secondary

Certificate

Diploma

Degree

Post Graduate

Others

5) Current Title

Health Worker

Teacher

NGO Worker

Local Leaders

Community Member

Other, Specify

SECTION B: ((Please tick one box for each construct item).

$1=$ "Strongly disagree" $2=$ "Disagree" 3 = "Not sure" $4=$ "Agree" $5=$ "Strongly agree"

\begin{tabular}{|c|c|c|c|c|c|c|}
\hline S/No. & Human Development & 1 & 2 & 3 & 4 & 5 \\
\hline 1. & Experiencing longer life & & & & & \\
\hline 2. & Access to health facilities & & & & & \\
\hline 3. & Access to safe water & & & & & \\
\hline 4. & Free and fair elections & & & & & \\
\hline 5. & Freedom of expression and association & & & & & \\
\hline 6. & High Primary school completion rates for both gender & & & & & \\
\hline 7. & High Proportion of pupils progressing to secondary school & & & & & \\
\hline 8. & All men and women have opportunities to improve or maintain their well-being & & & & & \\
\hline 9. & Health, education and police services are accessible & & & & & \\
\hline 10. & Quality public outputs & & & & & \\
\hline 11. & Property rights enforceable & & & & & \\
\hline
\end{tabular}




\section{Continued}

\section{Good Governance}

\section{Accountability}

1.

Government ensuring equal access to education by men and women

2.

Free quality services

3.

Regular and fair elections

4.

Compliance/adherence to legal requirements and administrative policies.

5.

Efficient and economical use of funds in construction of government buildings and other infrastructure.

6.

Decision-makers in government, the private sector and civil society organizations are accountable to the public

\section{Government efficiency}

Presence of simple procedures to ensure fair and swift action on suggestions, griev-

ances, etc. by the public.

2. Availability of information to the public on how the local government operates.

3. Awareness by the public to give feedback on how the local government's responds to local demands.

4.

Institutions and processes for salaries are efficient

5.

Institutions offer quality services for best use of resources

6.

$$
\text { Laws and regulations enforced impartially }
$$

\section{Participation}

1.

Existence of mechanisms that allow consultation between the local government and the urban constituents on various local concerns.

2.

Children are fully immunized

3.

Clearly defined mechanisms exist to ask users about their needs.

4.

Clearly defined mechanisms exist so that users can express their preferences

5. There is a clear understanding of what tasks and responsibilities leaders do perform.

6. Processes, institutions and information are directly accessible to those concerned with them

\section{Absence of Corruption}

1.

There is control of corruption in government

2 .

Progressive improvement of public services

3.

There are inconsistencies in the working conditions

4

Fairness and impartiality of rules and policies

Knows where to report a corrupt act

Leaders are fully responsible for their public actions

\section{Bribery}

1.

People offer money for something that is entitled to them by law. 